\title{
Molecular Analysis of the 9p21 Locus and p53 Genes in Ewing Family Tumors
}

\author{
José Antonio López-Guerrero, Antonio Pellín, Rosa Noguera, Carmen Carda, and \\ Antonio Llombart-Bosch
}

Department of Pathology, School of Medicine, University of Valencia, Valencia, Spain

SUMMARY: The EWS-ETS rearrangements, and their respective fusion gene products, are specifically associated with histopathologically Ewing family tumors (EFT). These translocations are implicated in generating malignant transformation of EFT, but the presence of additional genetic alterations must be considered in the pathogenesis of such tumors. We analyzed 26 samples (biopsies and/or nude mice xenotransplants) collected from 19 patients with an EFT to determine whether molecular and cytogenetic alterations of the $G_{1} / S$ checkpoint genes are implicated in the pathogenesis of EFT. We found inactivating p53 mutations in three (16\%) cases, which correlated with a loss of p21WAF1/Cip1 expression and with a monosomy of chromosome 17 in two cases. Homozygous deletion of the $\mathrm{p} 16^{\mathrm{INK} 4 \mathrm{~A}} / \mathrm{p} 14^{\mathrm{ARF}}$ gene was detected in four $(21 \%)$ cases, three with codeletion of the $\mathrm{p} 15^{\mathrm{INK} 4 \mathrm{~B}}$ gene and with chromosome 9 abnormalities. In all of these cases, expression of the implicated genes was absent. Hypermethylation of the $\mathrm{p} 16^{\mathrm{INK} 4 \mathrm{~A}}$ and $\mathrm{p} 15^{\mathrm{INK} 4 \mathrm{~B}}$ genes was detected in two $(10 \%)$ and three $(16 \%)$ cases, respectively, and was correlated with a low level of gene expression. Neither cyclin D1, nor MDM2 and CDK4 amplification was observed. Kaplan-Meier analysis showed that patients with tumors carrying homozygous deletion of the 9p21 locus, or point mutations of the p53 gene, had poorer outcomes than those without these molecular alterations $(p=0.005)$. In conclusion, $58 \%(11$ of 19$)$ of the analyzed patients showed genetic or epigenetic alterations in either the 9p21 locus or p53 tumor suppressor genes, defining a subgroup of patients with poor clinical outcome. This fact points to an important role of the $\mathrm{G}_{1} / \mathrm{S}$ cell cycle checkpoint dysregulation in the pathogenesis of EFT. (Lab Invest 2001, 81:803-814).

$T$ o progress through the cell cycle, mammalian cells must overcome the quiescent state of $G_{0}$ and enter the active $G_{1}$ cell cycle phase. In the $G_{1} / S$ cell cycle checkpoint control, cells integrate mitogenic and antimitogenic stimuli to decide to undergo division (Johnson and Walker, 1999; Liggett and Sidransky, 1998). This checkpoint is regulated mainly by the cyclin-dependent kinases (CDK4 or CDK6) bound to the D-type cyclins. These complexes phosphorylate to the product of the Rb tumor suppressor gene $(p R b)$ (Graña and Reddy, 1995; Sherr, 1996) and result in release of the E2F transcription factors that play a fundamental role in preparing the nucleus for DNA replication (Graña and Reddy, 1995; Huschtscha and Reddel, 1999; Johnson and Walker, 1999; Liggett and Sidransky, 1998; Sherr, 1996; Weinberg, 1995). CDK activity is influenced by a number of negative regulators: CDK inhibitors (CDKI) that physically associate with cyclins, CDK, or their complexes (MartínCastellanos and Moreno, 1997). Among these CDKI are p16 ${ }^{\text {INK4A }}$ (MTS1, CDKN2) (Kamb et al, 1994; Serrano et al, 1993) and p15 ${ }^{\mathrm{INK} 4 \mathrm{~B}}$ (MTS2) (Hannon and Beach, 1994), which form binary complexes exclu-

Received January 18, 2001.

This work was supported in part by Grants 1998 FIS number 98/0600 Madrid, Spain, from the Ministry of Health and 1997 AECC C-211/97 Valencia, Spain, from the Asociación Española Contra el Cáncer. Address reprint requests to: Professor Antonio Llombart-Bosch, Department of Pathology, School of Medicine, University of Valencia, Avda. Blasco Ibañez, 17, E-46010 Valencia, Spain. E-mail:antonio.llombart@uv.es sively with CDK4 and CDK6, inhibiting their function and, by so doing, inhibiting pRb phosphorylation during $\mathrm{G}_{1}$ (Graña and Reddy, 1995; Huschtscha and Reddel, 1999; Johnson and Walker, 1999; Liggett and Sidransky, 1998; Sherr, 1996; Weinberg, 1995). p16 ${ }^{\text {INK4A }}$ and p15 ${ }^{\text {INK4B }}$ genes map to the short arm of chromosome 9 (9p21-22), where they are found in tandem, spanning a region of approximately $80 \mathrm{~kb}$, with $\mathrm{p} 15^{\mathrm{INK} 4 \mathrm{~B}}$ located approximately $25 \mathrm{~kb}$ centromeric to the $\mathrm{p} 16^{\mathrm{INK} 4 \mathrm{~A}}$ gene. The $\mathrm{p} 15^{\mathrm{INK} 4 \mathrm{~B}}$ gene is composed of two exons and its protein is a transforming growth factor- $\beta$ (TFG- $\beta$ )-induced inhibitor (Hannon and Beach, 1994). The $\mathrm{p} 16^{\mathrm{INK} 4 \mathrm{~A}}$ gene contains three exons and exhibits two distinct transcripts derived from two alternative first exons, exon $1 \alpha$ and exon $1 \beta$ (13 kb centromeric to $1 \alpha$ ). The $\beta$ transcript contains a 5 ' initiation codon in exon $1 \beta$ and incorporates the exon-2 coding sequence in a reading frame different from that of the $\alpha$ transcript (Stone et al, 1995). The $\mathrm{p} 16^{\mathrm{INK} 4 \mathrm{~A}}$ protein is specified by the $\alpha$ transcript (exons $1 \alpha, 2$, and 3), and the alternatively spliced $\beta$ transcript (exons $1 \beta, 2$, and 3 ) encodes the $\mathrm{p} 14^{\mathrm{ARF}}$ protein in humans ( $p 19^{A R F}$ in mouse), which is a potent regulator of the cell cycle, functioning in a manner different from the CDKI (Liggett and Sidransky, 1998; Mao et al, 1995; Stone et al, 1995). p14 ${ }^{\mathrm{ARF}}$ acts upstream in the p53 pathway by binding to MDM2 and preventing p53 degradation, thus permitting p53-induced apoptosis or growth arrest (Lundberg and Weinberg, 1999; Sharpless and DePinho, 1999). 
The p53 protein, whose activity is modulated through its union to MDM2, also affects the $G_{1}$ to $S$ progression by increasing expression of another CDKI, p21 WAF1/Cip1, which is able to inhibit any cyclinCDK complexes, including D-type cyclin-CDK4/6 complexes (Johnson and Walker, 1999).

Molecular alterations in any of these genes affect the normal $G_{1}$ to $S$ transition and play an important role in human tumorigenesis. In this sense, mutations affecting the p53 tumor suppressor gene are the most common genetic alterations yet identified in sporadic human tumors (Hollstein et al, 1999), followed by genetic alterations of the 9p21 genes that have been demonstrated in a wide variety of neoplasms. However, the overall incidence of alterations is higher in tumor-derived cell lines than in primary tumors (Spruck et al, 1994).

Homozygous deletion of the 9p21 locus occurs frequently in bladder carcinomas, gliomas, T-cell acute lymphoblastic leukemias, melanomas, and renal carcinomas (Drexler, 1998; Kamb et al, 1994; Liggett and Sidransky, 1998; Nobori et al, 1994). These genes are also commonly inactivated by methylation of the $5^{\prime} \mathrm{CpG}$ islands of their promoter region in head and neck, lung, brain, breast, colon, esophageal, and bladder cancer (Esteller et al, 2000; Gonzalez-Zulueta et al, 1995; Merlo et al, 1995). On the other hand, aberrant methylation status has been found exclusively at the $\mathrm{p} 15^{\mathrm{INK} 4 \mathrm{~B}}$ gene in a high proportion of gliomas and leukemias (Drexler, 1998). Point mutation is a less common mechanism of inactivation of the 9p21 locus genes (Huschtscha and Reddel, 1999).

Ewing family tumors (EFT) are a subset of pediatric bone tumors, which include Askin tumors, Ewing's sarcoma, and peripheral primitive neuroectodermal sarcoma (pPNET). EFT are specifically associated with cytogenetic rearrangements (Delattre et al, 1994), with the resultant fusion genes involving EWS gene and members of the ETS family of transcription factors, which from a clinical point of view provide a valuable diagnostic and prognostic marker (de Alava et al, 1998a, 1998b; Kovar, 1998; Llombart-Bosch, 1999; Llombart-Bosch et al, 1990, 2000; Patiño-Garcia and Sierrasesúmaga, 1997; Pellín et al, 1994; Turc-Carel et al, 1988). EWS-ETS rearrangements are implicated in generating malignant transformation of EFT, but the presence of additional genetic alterations must be considered in their pathogenesis (Kovar, 1998; Llombart-Bosch, 1999). These genetic alterations might not necessarily be tumor-specific, but might display interindividual variation that could account for differences in EFT phenotype, as well as in clinical behavior, differentiation capacity, invasive potential, and treatment resistance (Kovar, 1998; LlombartBosch, 1999). Hence, knowledge of the nature of additional aberrations in EFT might assist subclassification and provide prognostic tools. In this sense, among genes implicated in the $\mathrm{G}_{1} / \mathrm{S}$ checkpoint, the $\mathrm{p} 16^{\mathrm{INK} 4 \mathrm{~A}}$ and $\mathrm{p} 15^{\mathrm{INK} 4 \mathrm{~B}}$ genes are lost from $0 \%$ to $30 \%$ in primary tumors (Kovar, 1998; Kovar et al, 1997; Llombart-Bosch, 1999; Park et al, 1999; Patiño-Garcia and Sierrasesúmaga, 1997; Wei et al, 2000), and 52\% in established cell lines (Kovar et al, 1997). The frequency of p53 mutations in primary tumors is less than 20\% (de Alava et al, 2000; Kovar, 1998; Kovar et al, 1997; Llombart-Bosch, 1999; Patiño-Garcia and Sierrasesúmaga, 1997), as opposed to a mean frequency of $40 \%$ to $60 \%$ in most human malignancies (Hollstein et al, 1999). Neither pRb molecular alterations nor D1-type cyclin genetic amplification are observed in EFT (Kovar, 1998; Kovar et al, 1997; Llombart-Bosch, 1999), although occasional low-level amplification of MDM2 and CDK4 has been reported (Kovar, 1998; Ladanyi et al, 1995).

The present study was undertaken to better understand the frequency of the molecular alterations of those tumor suppressor genes located on chromosome 9p21-22 in 26 samples (primary tumors and/or nude mice xenotransplants) collected from 19 patients with an EFT. We also evaluated alterations of p53 and genetic amplification of the cyclin D1, MDM2, and CDK4 genes in the same samples and analyzed their association with 9p21 locus alterations and their cytogenetic repercussion to determine whether, and to what extent, these genes are implicated in the development and progression of this subset of pediatric bone tumors.

\section{Results}

\section{Analysis of the 9p21 Locus Genes}

Homozygous deletion of the 9p21 locus genes was not found in any primary tumor (PT), although deletion of $\mathrm{p} 16^{\mathrm{INK} 4 \mathrm{~A}}$ was observed in 4 of 12 nude mice xenotransplants (NMX), of which three also had codeletion of the $\mathrm{p} 14^{\mathrm{ARF}}$ and $\mathrm{p} 15^{\mathrm{INK} 4 \mathrm{~B}}$ genes. NMX from Case 19 maintained the exon $1 \beta$ of $\mathrm{p} 14^{\mathrm{ARF}}$ and the exons 1 and 2 of $\mathrm{p} 15^{\text {INK4B }}$ (Fig. 1; Table 1). In all of these samples, neither $\mathrm{p} 16^{\mathrm{INK} 4 \mathrm{~A}}$ nor $\mathrm{p} 14^{\mathrm{ARF}}$ and $\mathrm{p} 15^{\text {INK4B }}$ transcripts were detected by RT-PCR, including in the NMX of Case 19. Thus, from all the patients analyzed, 4 of $19(21 \%)$ presented homozygous deletion of the $\mathrm{p} 16^{\mathrm{INK} 4 \mathrm{~A}} / \mathrm{p} 14^{\mathrm{ARF}}$ gene, from

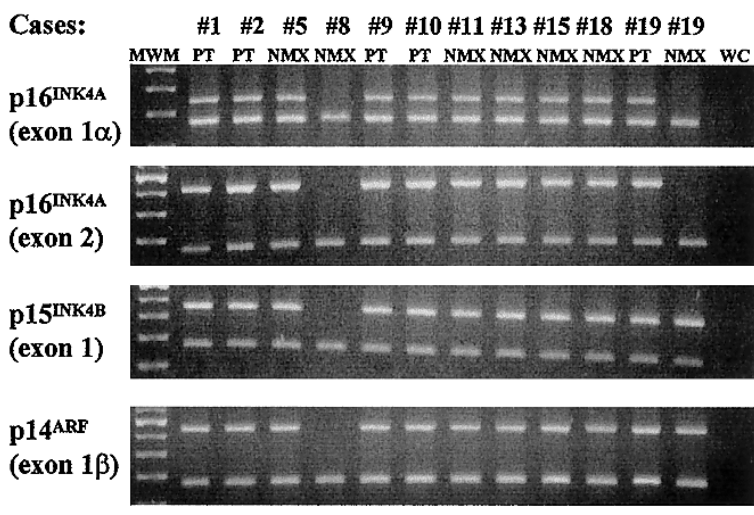

Figure 1.

Representative analysis of the homozygous deletion of the 9p21 locus genes. Case 8 shows a complete deletion of these genes, whereas NMX from Case 19 retains the $\mathrm{p} 15^{\mathrm{INK} 4 \mathrm{~B}}$ gene and the exon $1 \beta$ of the $\mathrm{p} 14^{\mathrm{ARF}}$ gene. MWM, molecular weight marker; PT, primary tumor; NMX, nude mice xenotransplant; WC, water control. 


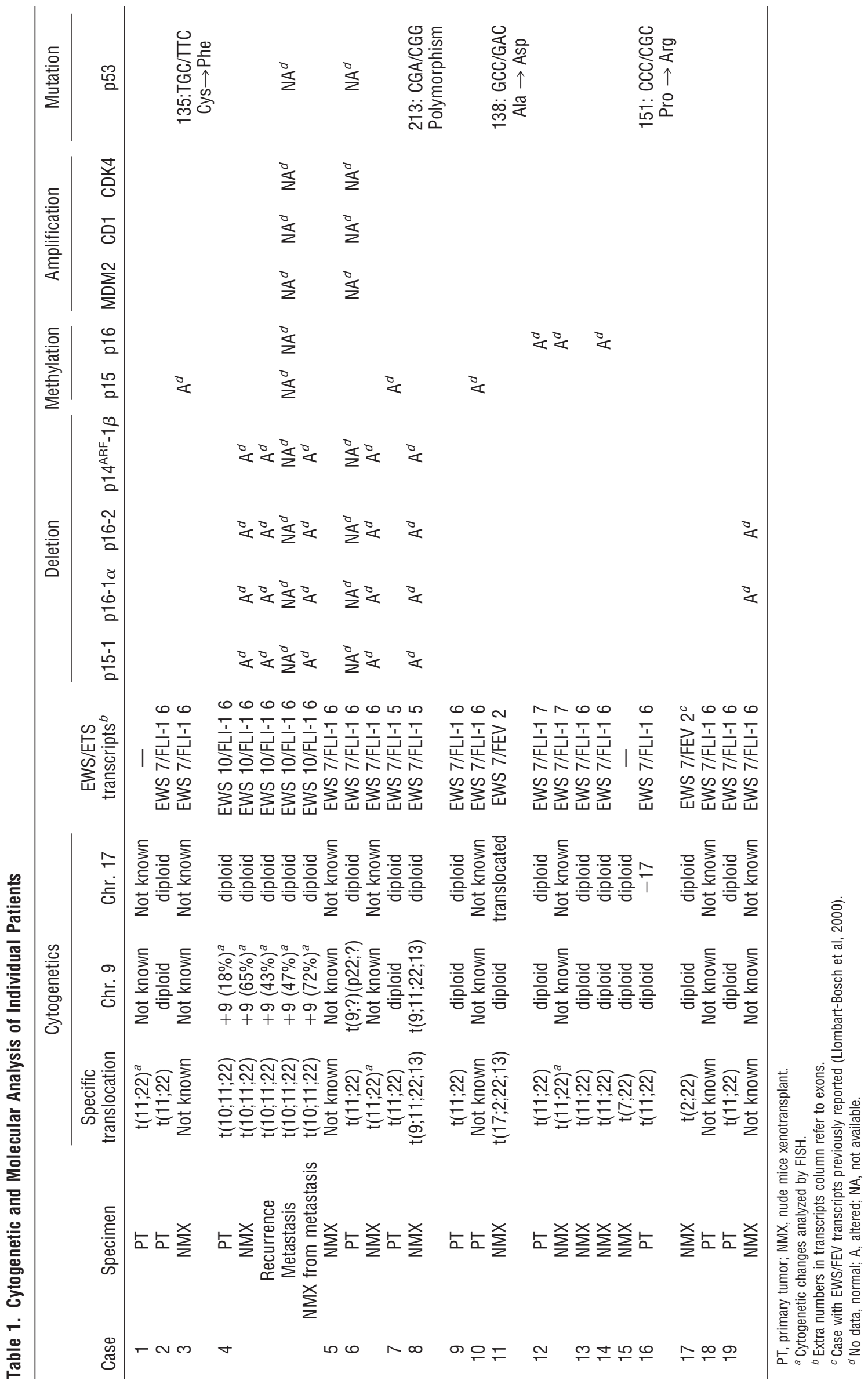


which three (16\%) were accompanied by the $\mathrm{p} 15^{\mathrm{INK} 4 \mathrm{~B}}$ gene. Cytogenetically, two of these cases showed translocations involving chromosome 9p21-22 (Table 1). It is noteworthy that in Case 4, in particular, from which samples of PT, NMX from PT, recurrence, metastasis, and NMX from metastasis were available, deletion of the 9p21 locus genes (Fig. 2A), with the corresponding loss of expression (Fig. 2B), was always detected, except in the PT sample (Table 1). This indicates that this molecular alteration persisted during the tumoral progression and that it was already present in the PT. Although no abnormalities of chromosome 9 were detected in the metaphases from the direct samples of this case, by the fluorescence in situ hybridization (FISH) technique, a progressive gain of material of chromosome 9 was seen in the interphase nuclei from the successive samples of this particular case (Table 1).

Samples without homozygous deletion of the 9p21 genes were analyzed for the methylation status of the $5^{\prime} \mathrm{CpG}$ island of the $\mathrm{p} 15^{\mathrm{INK} 4 \mathrm{~B}}$ and $\mathrm{p} 16^{\mathrm{INK} 4 \mathrm{~A}}$ genes. Aberrant hypermethylation in the promoter region of the $\mathrm{p} 16^{\mathrm{INK} 4 \mathrm{~A}}$ gene was observed in Cases 12 (Fig. 3) and 14 (Table 1). For p15 ${ }^{\mathrm{INK} 4 \mathrm{~B}}$ methylation status, Cases 3, 7, and 10 were found to be hypermethylated (Fig. 3; Table 1). Hypermethylation of both genes in the same sample was not coincident, but was associated with a low level of expression of the corresponding gene.

\section{p53 Analysis and p21 WAF1/Cip1 Expression}

We analyzed exons 5 through 8 of the p53 tumor suppressor gene because this region accounts for approximately $80 \%$ of the conserved domains of the gene and is the location of more than $95 \%$ of the mutations reported in sporadic tumors.

We detected point mutations in three samples corresponding to Cases 3,11 , and 16, making an incidence of $16 \%$ of the cases studied. All mutations were located in exon 5 of the p53 gene (Table 1), and are correlated-except for Case 16 where no RNA was available-with the low level or loss of p21 WAF1/Cip1

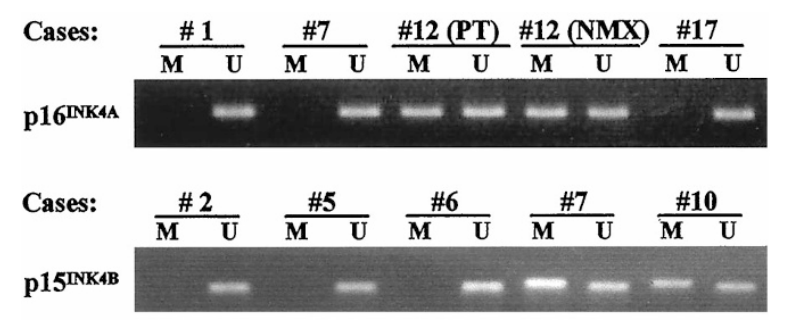

Figure 3.

Representative analysis of the methylation status of the $\mathrm{p} 16^{\mathrm{INK} 4 \mathrm{~A}}$ and $\mathrm{p} 15^{\mathrm{INK} 4 \mathrm{~B}}$ tumor suppressor genes. $M$, methylated; and $U$, unmethylated primers.

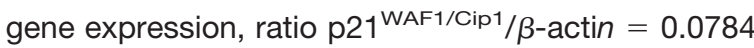
or $0 \mathrm{AU}$ (arbitrary units) for Cases 3 and 11, respectively (Fig. 4). Nonrandom loss of one homolog of chromosome 17 was detected in Cases 11 and 16.

Recognition of the R213R polymorphism at exon 6 of the p53 gene was observed in Case 8 (Table 1).

\section{Amplification of the MDM2, Cyclin D1, and CDK4 Genes}

All cases were also analyzed for the MDM2, cyclin D1, and CDK4 amplifications by dPCR methods; however, no amplifications in any of these genes were observed.

Table 1 summarizes the results obtained from the analysis of the status of the 9p21 locus for p53, MDM2, cyclin D1, and CDK4 alterations. There was no association between $\mathrm{p} 16^{\mathrm{INK} 4 \mathrm{~A}} / \mathrm{p} 14^{\mathrm{ARF}}$ status and $\mathrm{p} 53$ mutations. The sample from Case 3 , however, showed p53 mutation with hypermethylation of the p15 1 KK4B gene. As a whole, 58\% (11 of 19) of the analyzed patients showed genetic or epigenetic alterations in one or more of the $\mathrm{p} 16^{\mathrm{INK} 4 \mathrm{~A}}, \mathrm{p} 15^{\mathrm{INK} 4 \mathrm{~B}}, \mathrm{p} 14^{\mathrm{ARF}}$, or p53 tumor suppressor genes, indicating the important role of these regulators of the $G_{1} / S$ checkpoint in the pathogenesis of EFT.

\section{Molecular Alterations and Follow-Up}

The median follow-up for 18 of 19 patients was 22.5 months (range, 5-150 months), from which four re-
(A)

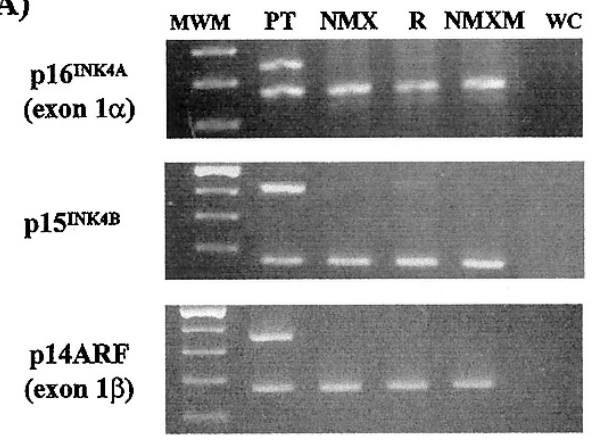

(B)

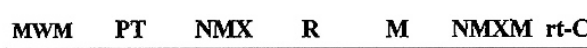

p16 ${ }^{\mathrm{INK} 4 \mathrm{~A}}$

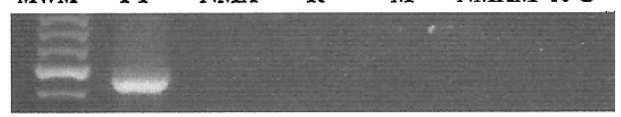

p15 INK4B

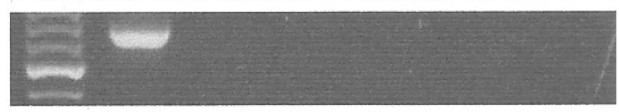

p14ARF

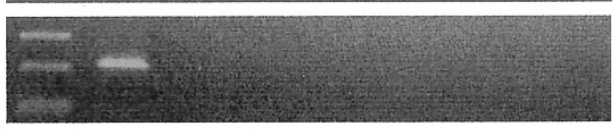

$\beta$-actin

Figure 2.

Case 4. A, Deletion of the 9p21 genes was not found in the primary tumor (PT); however, it was observed in the nude mice xenotransplant (NMX) from the PT, in the recurrence $(R)$ and in the NMX from metastasis $(M)$. B, Deletion of the $9 p 21$ genes was correlated with the loss of their expression. WC, water control; rt-C, RT-PCR control. 


\section{Wild type: \\ 5'-CTGGCCAAGACCTGCC-3' CD138}

CD138 mutation (case \#11): GCC to GAC

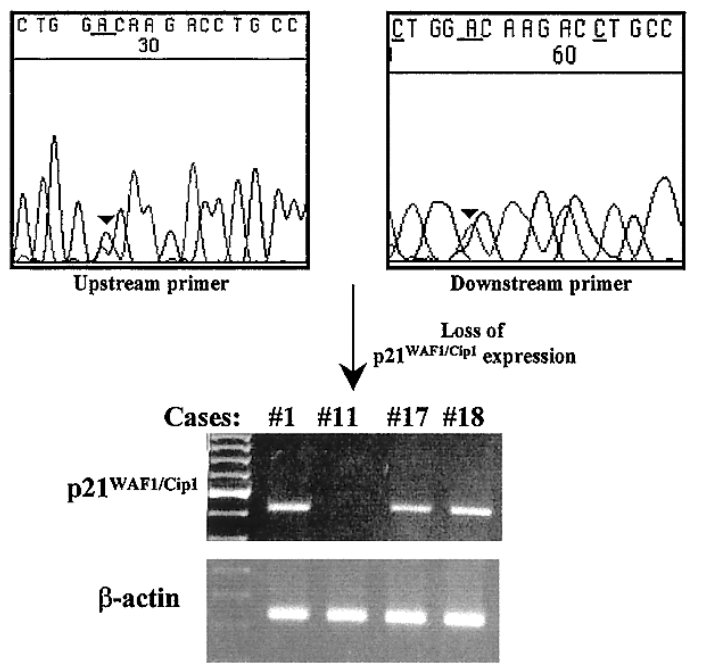

Figure 4.

Inactivating point mutation of the p53 tumor suppressor gene corresponding to Case 11 , which correlates with the loss of p21 WAF1/Cip1 gene expression.

mained alive and without evidence of disease during this period (Table 2). Association between molecular findings and follow-up indicated that none of the surviving patients presented molecular alterations of the $G_{1} / S$ checkpoint regulator genes. However, homozygous deletion of the 9p21 locus or point mutations of the p53 gene were present in tumors of patients with the poorest outcomes (Fig. 5A; Table 3). Moreover, when complete inactivation of the 9p21 locus (homozygous deletion) or p53 genes was considered as a whole, as representative of the inactivation of the $\mathrm{G}_{1} / \mathrm{S}$ checkpoint, we observed that patients with an EFT carrying any of these alterations showed an overall survival time shorter than those without these alterations (Fig. 5B; Table 3).

\section{Discussion}

Genetic mutations in the regulatory genes implicated in cell cycle control can be considered to target one of two critical pathways: the $\mathrm{pRb}$ pathway that regulates $\mathrm{G}_{1} / \mathrm{S}$-phase transition and the p53 pathway that induces growth arrest or apoptosis in response to either DNA damage or inappropriate mitogenic stimuli (Sharpless and DePinho, 1999). Molecular alterations of the integrating elements of either pRb, p53, or both pathways suppress their normal function, abrogating regulation of cell cycle transition from $\mathrm{G}_{1}$ to $\mathrm{S}$-phase and driving cells to proliferation. In EFT, these molecular alterations might constitute part of a multistep process with equivalent cellular effects, of which the EWS-ETS genetic fusion seems to be the initiating mechanism of EFT pathogenesis (Kovar, 1998; Llombart-Bosch, 1999).

Currently, in EFT, few studies have reported the frequency of homozygous deletions of the $\mathrm{p} 16^{\mathrm{INK} 4 \mathrm{~A}}$ tumor suppressor gene, which is normally accomplished with the codeletion of the $\mathrm{p} 15^{\mathrm{INK} 4 \mathrm{~B}}$ and p14 ${ }^{\mathrm{ARF}}$ genes, being of one-third for PT and more than $50 \%$ in tumor cell lines from unrelated patients (Kovar, 1998; Kovar et al, 1997; Llombart-Bosch, 1999; Park et al, 1999; Patiño-Garcia and Sierrasesúmaga, 1997;

Table 2. Clinical Data for Patients

\begin{tabular}{|c|c|c|c|c|c|}
\hline \multirow[b]{2}{*}{ Case } & \multirow[b]{2}{*}{ Age/Sex } & \multirow[b]{2}{*}{ Primary site } & \multirow[b]{2}{*}{ Treatment } & \multicolumn{2}{|r|}{ Follow-up } \\
\hline & & & & Metastasis & Last known status \\
\hline 1 & $20 / \mathrm{M}$ & Scapula & $\mathrm{S}+\mathrm{CT}+\mathrm{RT}$ & None & Alive and NED 48 months \\
\hline 2 & $2 / \mathrm{M}$ & Bone marrow & N/A & $\mathrm{N} / \mathrm{A}$ & $\mathrm{N} / \mathrm{A}$ \\
\hline 3 & $13 / \mathrm{M}$ & Pubis & $\mathrm{S}+\mathrm{CT}+\mathrm{RT}$ & Multiple & Death 5 months \\
\hline 4 & $11 / F$ & Perone & $\mathrm{S}+\mathrm{CT}+\mathrm{RT}+\mathrm{T}$ & Lung & Death 19 months \\
\hline 5 & $16 / \mathrm{M}$ & Soft tissue thigh & $\mathrm{S}+\mathrm{CT}$ & None & Alive and NED 150 months \\
\hline 6 & $12 / F$ & Homoplat & $\mathrm{S}+\mathrm{CT}+\mathrm{RT}$ & Multiple & Death 10 months \\
\hline 7 & $38 / \mathrm{M}$ & Retroperitoneum & $\mathrm{S}+\mathrm{CT}+\mathrm{RT}$ & Multiple & Death 22 months \\
\hline 8 & $14 / \mathrm{M}$ & Soft tissue thigh & $\mathrm{S}+\mathrm{CT}+\mathrm{RT}+\mathrm{T}$ & Multiple & Death 9 months \\
\hline 9 & $20 / \mathrm{M}$ & Femur & $\mathrm{S}+\mathrm{CT}+\mathrm{RT}$ & Lung & Death 12 months \\
\hline 10 & $19 / \mathrm{M}$ & Rib & $\mathrm{S}+\mathrm{CT}+\mathrm{RT}$ & Lung & Death 47 months \\
\hline 11 & $24 / \mathrm{M}$ & Retroperitoneum & $\mathrm{S}+\mathrm{CT}$ & Multiple & Death 12 months \\
\hline 12 & $9 / \mathrm{M}$ & Radius & $\mathrm{S}+\mathrm{CT}$ & None & Alive and NED 138 months \\
\hline 13 & $21 / F$ & Soft tissue thigh & $\mathrm{S}+\mathrm{CT}+\mathrm{RT}$ & Multiple & Death 48 months \\
\hline 14 & $16 / \mathrm{M}$ & Soft tissue ankle & $\mathrm{S}+\mathrm{CT}+\mathrm{RT}$ & Multiple & Death 78 months \\
\hline 15 & $20 / F$ & Pelvis & $\mathrm{S}+\mathrm{CT}+\mathrm{RT}$ & Multiple & Death 14 months \\
\hline 16 & $16 / \mathrm{M}$ & Vertebral & $\mathrm{S}+\mathrm{CT}+\mathrm{RT}$ & Lung & Death 23 months \\
\hline 17 & $15 / \mathrm{M}$ & Soft tissue inguen & $\mathrm{S}+\mathrm{CT}+\mathrm{RT}+\mathrm{T}$ & Multiple & Death 28 months \\
\hline 18 & $35 / \mathrm{M}$ & Soft tissue thigh & $\mathrm{S}+\mathrm{CT}+\mathrm{RT}$ & None & Alive and NED 90 months \\
\hline 19 & $17 / \mathrm{M}$ & Scapula & $\mathrm{S}+\mathrm{CT}$ & Multiple & Death 19 months \\
\hline
\end{tabular}

S, surgery; CT, chemotherapy; RT, radiation therapy; T, autologous bone marrow transplantation; NED, no evidence of disease; N/A, information not available. 
(A)

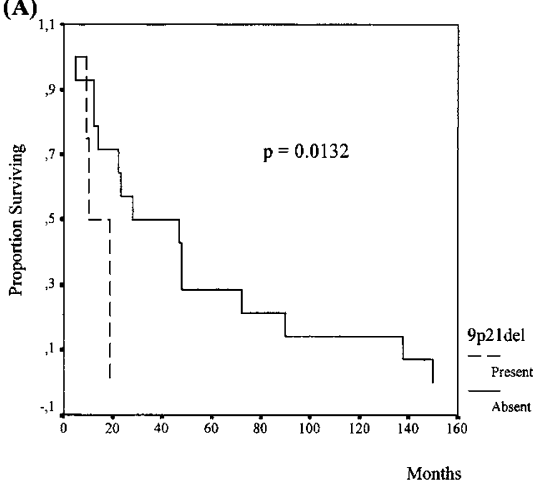

(B)

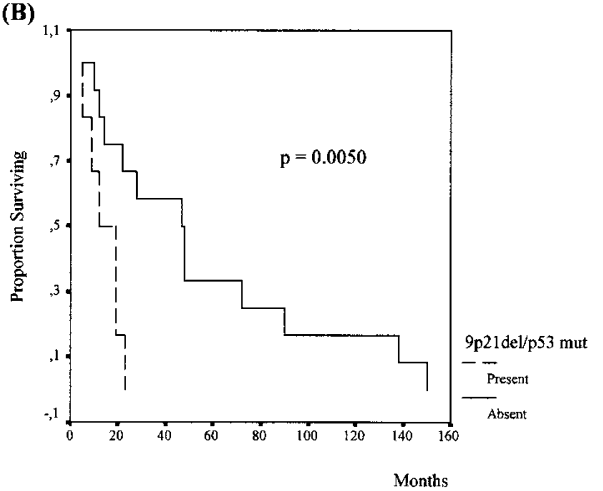

Figure 5.

Kaplan-Meier survival plots showing the prognosis for patients with $(A)$ homozygous deletion of the $9 p 21$ locus genes or $(B)$ inactivation of $G_{1} / S$ checkpoint (homozygous deletion of the 9p21 or inactivating point mutations of the p53 tumor suppressor gene).

Table 3. Kaplan-Meier Analysis of Molecular Alterations of the 9p21 Locus and p53 Tumor Suppressor Genes with Follow-Up

\begin{tabular}{|c|c|c|c|c|c|}
\hline Molecular status & $n$ & $\begin{array}{l}\text { Median } \\
\text { (months) }\end{array}$ & $\begin{array}{l}\text { Range } \\
\text { (months) }\end{array}$ & Log Rank & $p$ value \\
\hline \multicolumn{6}{|c|}{ Homozygous deletion of the $9 p 21$ genes } \\
\hline Absent & 14 & 28 & $5-150$ & 6.14 & 0.0132 \\
\hline Present & 4 & 10 & $9-19$ & & \\
\hline \multicolumn{6}{|c|}{ Hypermethylation of $\mathrm{p} 15^{\mathrm{INK} 4 \mathrm{~B}} / \mathrm{p} 16^{\text {INK4A }}$} \\
\hline Absent & 13 & 19 & $9-150$ & 0.18 & 0.6689 \\
\hline Present & 5 & 47 & $5-138$ & & \\
\hline \multicolumn{6}{|c|}{ Molecular alterations of the $9 p 21$ genes $^{a}$} \\
\hline Absent & 9 & 28 & $12-150$ & 0.82 & 0.3646 \\
\hline Present & 9 & 19 & $5-138$ & & \\
\hline \multicolumn{6}{|l|}{ Point mutations of p53 } \\
\hline Absent & 15 & 28 & $9-150$ & 3.62 & 0.0571 \\
\hline Present & 3 & 12 & $5-23$ & & \\
\hline \multicolumn{6}{|c|}{$\begin{array}{l}\text { Homozygous deletion of the } 9 p 21 \text { genes } \\
\text { or p53 point mutations }\end{array}$} \\
\hline Absent & 11 & 47 & $10-150$ & 7.88 & 0.0050 \\
\hline Present & 7 & 12 & $5-23$ & & \\
\hline \multicolumn{6}{|c|}{$\begin{array}{l}\text { Molecular alterations of the } 9 p 21 \text { genes } \\
\text { or p53 point mutations }\end{array}$} \\
\hline Absent & 7 & 48 & $12-150$ & 1.88 & 0.1704 \\
\hline Present & 11 & 18 & $5-138$ & & \\
\hline
\end{tabular}

${ }^{a}$ Molecular alterations of the 9p21 genes include epigenetic and genetic changes (hypermethylation and homozygous deletion).

Tsuchiya et al, 2000; Wei et al, 2000). These percentages were clearly higher than those observed in other soft-tissue sarcomas in which incidence of molecular alterations of the $9 \mathrm{p} 21$ locus genes ranged from $0 \%$ to 15\% (Meye et al, 1998; Orlow et al, 1999; SchneiderStock et al, 1997; Wei et al, 1999; Yao et al, 1998), indicating that inactivation of these tumor suppressor genes might play an important role in the pathogenesis of EFT. On the other hand, p53 mutations have been reported in approximately $20 \%$ of EFT (de Alava et al, 2000; Kovar, 1998; Kovar et al, 1997; LlombartBosch, 1999; Patiño-Garcia and Sierrasesúmaga, 1997), whereas neither molecular alterations of the pRb gene nor D1-type cyclin genetic amplification have been observed (Kovar, 1998; Kovar et al, 1997; Llombart-Bosch, 1999), although an occasional low level of MDM2 and CDK4 amplification has been reported (Kovar, 1998; Ladanyi et al, 1995). However, amplification of the $12 \mathrm{q} 13$ locus, where MDM2 and CDK4 are located, is a frequent event in other softtissue sarcomas (Khatib et al, 1993; Wei et al, 1999).

Among the main mechanisms of the 9p21 locus gene inactivation are deletion and hypermethylation of the $5^{\prime} \mathrm{CpG}$ islands of their promoter region (Esteller et al, 2000; Gonzalez-Zulueta et al, 1995; Herman et al, 1996; Kamb et al, 1994; Merlo et al, 1995). In this sense, in our study we identified deletion of the $\mathrm{p} 16^{\mathrm{INK} 4 \mathrm{~A}} / \mathrm{p} 14^{\mathrm{ARF}}$ gene in four $(21 \%)$ cases, of which three had also codeletion of the $\mathrm{p} 15^{\mathrm{INK} 4 \mathrm{~B}}$ gene and aberration of chromosome 9. The NMX from Case 19 maintained exon $1 \beta$ of the $\mathrm{p} 14^{\mathrm{ARF}}$ gene and the two exons of the p1 $15^{\mathrm{INK} 4 \mathrm{~B}}$. Nonetheless, no expression of 
these genes was observed. A cryptic microdeletion, not observed by cytogenetics, affecting the complete sequence of the $\mathrm{p} 16^{\mathrm{INK} 4 \mathrm{~A}}$ gene, including exon 2 shared with $\mathrm{p} 14^{\mathrm{ARF}}$, might be the basis for this finding, as well as in the loss of the p15 1 INK4B expression. A similar case with a deletion adjacent to $\mathrm{p} 15^{\mathrm{INK} 4 \mathrm{~B}}$, affecting the $\mathrm{p} 16^{\mathrm{INK} 4 \mathrm{~A}} / \mathrm{p} 14^{\mathrm{ARF}}$ gene, was previously reported (Jen et al, 1994).

On the other hand, methylation analysis, by methylation-specific PCR (MSP), showed p16 INK4A hypermethylation in $10 \%$ of the patients, whereas $\mathrm{p} 15^{\mathrm{INK} 4 \mathrm{~B}}$ hypermethylation was observed in $16 \%$. In our cases, this alteration never correlated with the total loss of RNA expression because of the incomplete hypermethylation of the $\mathrm{p} 16^{\mathrm{INK} 4 \mathrm{~A}}$ and $\mathrm{p} 15^{\mathrm{INK} 4 \mathrm{~B}}$ alleles, as the amplification with unmethylated primers showed. In Case 12, such PT as its NMX presented showed hypermethylation of the $\mathrm{p} 16^{\text {INK4A }}$ gene, suggesting that some tumor cells, with inactivated p16 ${ }^{\text {INK4A }}$ gene in the PT, provided some proliferative advantage that was maintained through their growth in the NMX. Contrary to deletion, p16 $6^{\mathrm{INK} 4 \mathrm{~A}}$ and $\mathrm{p} 15^{\mathrm{INK} 4 \mathrm{~B}}$ genes never are cohypermethylated in the same sample, indicating that this epigenetic change is a more selective mechanism of gene inactivation whose role in EFT tumorigenesis remains to be clarified.

In Cases 4, 6, and 19, with paired samples of PT and NMX from PT, we observed deletion of the 9p21 genes in the NMX but not in the PT. The study of surgical specimens from many human cancer categories reveals a lower proportion of cases with 9p21 deletion than cell lines established from them (Cairns et al, 1994; Drexler, 1998; Kamb et al, 1994; Kovar et al, 1997; Nobori et al, 1994; Okamoto et al, 1994), because admixed nonneoplastic cells render the demonstration of deletion by differential PCR more difficult, and/or because small clones of tumoral cells within the tumor carrying 9p21 deletion might not be detected. Many cancers contain cell populations that escape from the normal limitations on proliferative potential, becoming immortals (Huschtscha and Reddel, 1999). A frequent change observed in these immortalized cells is the loss of p16 INK4A $^{\text {function }}$ (Huschtscha and Reddel, 1999; Okamoto et al, 1994). Thus, it might be easier to establish cell lines from tumors that have undergone molecular alterations of the 9p21 locus during their development in vivo (Drexler, 1998; Huschtscha and Reddel, 1999), although these alterations were present in only a small proportion of cells. These observations are similar to our cases with respect to the NMX. Available samples from Case 4 especially reinforce this theory. Molecular alterations of the 9p21 locus were not found in the PT, although in the NMX from the PT, recurrence and, in the NMX from the metastasis, loss of expression and homozygous deletion of these genes were observed. From the metastasis we were able to confirm only the loss of expression. These results show that deletion of the 9p21 locus was clearly manifested during tumor progression and that it was already present in the primary sample, but in a small tumoral cell population. We reached this conclusion because homozygous deletion of 9p21 was detected in the NMX from the PT and in the recurrence and metastasis. Direct association between the detection of 9p21 deletion by differential PCR with the gain of chromosome 9, observed by $\mathrm{FISH}$, suggests that cells with an extra copy of chromosome 9 are carriers of a cryptic microdeletion of the 9p21 locus. In fact, we were not able to detect this deletion in the PT where the percentage of cells with a gain of chromosome 9 was only $18 \%$ compared with the rest of the samples with a higher proportion of cells with gains of chromosome 9 . Thus, loss of 9p21 locus in this case confers a proliferating advantage that selects this tumoral clone.

We found a significant association with a poor overall survival in those patients with an EFT carrying homozygous deletion of the 9p21 locus. Kovar et al (1997) were the first to suggest the prognostic implication of the 9p21 alterations in patients with Ewing sarcoma. Later, Tsuchiya et al (2000) and, more clearly, Wei et al (2000) confirmed this. The study of Wei et al is particularly important because it is the only one that, in a multivariate analysis of disease-specific survival, found 9p21 locus deletion to be a significant negative prognostic factor, independent of stage at diagnosis. Unlike the study of Wei et al, we also analyzed the effect of the methylation status of the $\mathrm{p} 16^{\mathrm{INK} 4 \mathrm{~A}} / \mathrm{p} 15^{\mathrm{INK} 4 \mathrm{~B}}$ genes on overall survival. Our data suggest that 9p21 homozygous deletion, but not $\mathrm{p} 16^{\mathrm{INK} 4 \mathrm{~A}} / \mathrm{p} 15^{\mathrm{INK} 4 \mathrm{~B}}$ hypermethylation, adversely affects the prognosis of EFT patient.

We also detected inactivating mutations of the p53 gene in three $(16 \%)$ cases, which correlated with low or no expression of the p21 WAF1/Cip1 gene, and with nonrandom loss of one homolog of chromosome 17 in two cases. EFT patients with point mutations of p53 showed a trend toward a poorer overall survival, which agrees with studies reported by Abudu et al (1999) and de Alava et al (2000), based on immunohistochemical analysis, which show that p53 alterations appear to define a clinical subset of patients with a markedly poor outcome that is independent of site, local treatment, or necrosis of the tumors. Thus, in spite of the rarity of abnormalities of the p53 gene in EFT, they might indicate the assumption of a more aggressive outcome constituting an independent poor prognostic factor in EFT (Abudu et al, 1999).

The recent evidence that the $\mathrm{p} 16^{\mathrm{INK} 4 \mathrm{~A}} / \mathrm{p} 14^{\mathrm{ARF}}$ locus encodes two products (Sharpless and DePinho, 1999) that affect the $\mathrm{pRb}$ and $\mathrm{p} 53$ pathways, positions the $\mathrm{p} 16^{\mathrm{INK} 4 \mathrm{~A}} / \mathrm{p} 14^{\mathrm{ARF}}$ gene at the nexus of the two most critical tumor-suppressor pathways governing neoplasia. Homozygous deletion of the 9p21 locus deregulates the $\mathrm{G}_{1} / \mathrm{S}$-phase transition by causing the simul-

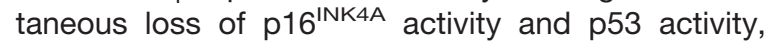
because of the absence of p14 ${ }^{\mathrm{ARF}}$ (Sharpless and DePinho, 1999). Nonetheless we did not find any significant differences for the p21 WAF1/Cip1 expression between those cases with and without alterations of the 9p21 locus, indicating that inactivation of the $\mathrm{p} 16^{\mathrm{INK} 4 \mathrm{~A}} / \mathrm{p} 14^{\mathrm{ARF}}$ gene might not be functionally equivalent to alterations in p53, but still might produce aggressive biologic behavior. In our cases, p53 point 
mutations were not associated with molecular alterations of the 9p21 locus; however, as a whole, they define a subset of patients whose tumors present the $\mathrm{G}_{1} / \mathrm{S}$ checkpoint clearly disrupted, and whose clinical evolution was the poorest. The possible significance of the inactivated $G_{1} / S$ checkpoint in identifying a subset of EFT patients with a poor prognosis merits a more systematic combined analysis of the 9p21 locus and p53 alterations to stratify patients into favorable and unfavorable groups, who might benefit from alternative treatments.

We did not detect genetic alterations of the CDK4 and MDM2 genes, both located in the chromosome 12q13, a region frequently amplified in non-EFT softtissue sarcomas (Khatib et al, 1993; Wei et al, 1999). In our study, in all cases cytogenetically analyzed, chromosome 12 was apparently normal. However, deletion of the 9p21 eliminates $\mathrm{p} 16^{\mathrm{INK} 4 \mathrm{~A}}$ and $\mathrm{p} 14^{\mathrm{ARF}}$ genes, which interact with the CDK4 and MDM2, respectively. Hence, alterations of the 9p21 and 12q13 might be redundant, and although they functionally represent similar effects, they are clearly implicated in the development of different pathologies.

In conclusion, our study shows that the genetic and epigenetic alteration in the 9p21 locus eliminates three important cell-growth inhibitors (p16 ${ }^{\text {INK4A }}, p 14^{\mathrm{ARF}}$, and $\mathrm{p} 15^{\mathrm{INK} 4 \mathrm{~B}}$ ) but constitutes the second molecular event in importance, after the EWS/ETS rearrangements, in the pathogenesis of EFT. Alterations in the p53 gene have been observed to a lesser extent. However, as a whole, $58 \%$ of the analyzed patients showed alterations of these important $G_{1} / S$ checkpoint regulators. In this sense, the Kaplan-Meier analysis showed that patients with EFT carrying homozygous deletion of the 9p21 locus or p53 point mutations (ie, with inactivated $\mathrm{G}_{1} / \mathrm{S}$ checkpoint control) had a significantly poorer outcome than those without evidence of these molecular alterations. This fact points to an important role for the $\mathrm{G}_{1} / \mathrm{S}$ cell cycle checkpoint dysregulation in the pathogenesis and clinical behavior of EFT, indicating that further studies with more patients and with combined analysis of 9p21 homozygous deletions and p53 abnormalities are necessary.

\section{Material and Methods}

\section{Samples and Patients}

We analyzed freshly frozen material from 26 samples, including PT and/or NMX, from 19 patients with an EFT admitted to the Department of Pathology at the Medical School in Valencia, Spain. Some cases had been characterized previously by ultrastructural and immunohistochemistry (Llombart-Bosch et al, 1990). The most relevant clinical data from our cases are shown in Table 2. Follow-up was available in 18 patients (median, 22.5 months; range, 5-150 months); four patients survived without evidence of disease for this period. Presence of EWS/ETS rearrangements was confirmed by RT-PCR in all tumor samples, except for Cases 1 and 15 for which no RNA was available, but with the $t(11 ; 22)$ and $t(7 ; 22)$ confirmed by FISH and cytogenetics respectively (Table 1). Samples from PT, NMX from PT, recurrence, metastasis, and NMX from metastasis were available from Case 4 (Table 2).

DNA and RNA were isolated from frozen tissue samples. High molecular weight DNA was obtained with proteinase K (Life Technologies, Gaithersburg, Maryland) digestion and purification by a conventional phenol-chloroform protocol, whereas total RNA extraction was performed according to the manufacturer's instructions using TRIzol Reagent (Life Technologies) $1 \mathrm{ml} / 50 \mathrm{mg}$ of tissue. Both DNA and RNA were quantified by spectrophotometry at $260 \mathrm{~nm}$, and RNA integrity was checked by $1 \%$ ultraPURE agarose (Life Technologies, Paisley, Scotland) gel electrophoresis and ethidium-bromide staining.

\section{Analysis of the 9p21 Locus}

Homozygous Deletion of the $p 15^{I N K 4 B}, p 16^{I N K 4 A}$, and $p 14^{A R F}$ Genes. Differential PCR (dPCR) was used to detect homozygous deletion of the 9p21 genes. In this assay, a simultaneous amplification of genomic DNA was performed by using two sets of primers, one to the target gene sequence under study and the other to target the $\beta$-globin gene, which was used as internal control for DNA quality and loading. Each 25- $\mu$ l PCR reaction contained $250 \mathrm{ng}$ of genomic DNA, 1x PCR buffer II (100 mm Tris- $\mathrm{HCl}, 500 \mathrm{~mm} \mathrm{KCl}$, $\mathrm{pH}$ 8.3) (Perkin-Elmer, Norwalk, Connecticut), $2 \mathrm{~mm}$ $\mathrm{MgCl}_{2}, \quad 0.2 \mathrm{~mm}$ dNTPs (Life Technologies), 10\% DMSO (Sigma Chemical, St. Louis, Missouri), $0.6 \mathrm{U}$ AmpliTaq (Perkin-Elmer) and $0.2 \mu \mathrm{M}$ for each set of primers (PE-Applied Biosystems, Warrington, United Kingdom). PCR was carried out in a DNA Thermal Cycler 9600 (Perkin-Elmer) wherein the samples were preheated at $95^{\circ} \mathrm{C}$ for 5 minutes and amplified as follows: 30 cycles for p15 $5^{\mathrm{INK} 4 \mathrm{~B}}$ exon 1 and $\mathrm{p} 16^{\mathrm{INK} 4 \mathrm{~A}}$ exon 2,35 cycles for $\mathrm{p} 16^{\mathrm{INK} 4 \mathrm{~A}}$ exon $1 \alpha$, and 28 cycles for $\mathrm{p} 14^{\mathrm{ARF}}$ exon $1 \beta$, with a final extension step of $72^{\circ} \mathrm{C}$ for 10 minutes. Primers, annealing temperature, and PCR product sizes are summarized in Table 4. The amplification products were visualized on an ethidium-bromide-stained $1.5 \%$ agarose gel. The presence of homozygous deletion was determined by the loss of the PCR product corresponding to $\mathrm{p} 15^{\mathrm{INK} 4 \mathrm{~B}}, \mathrm{p} 16^{\mathrm{INK} 4 \mathrm{~A}}$, and $\mathrm{p} 14^{\mathrm{ARF}}$ genes with the presence of the $\beta$-globin amplification. A water control, with no DNA, was included in each experiment.

Methylation-Specific PCR (MSP). The methylation status of the $5^{\prime} \mathrm{CpG}$ island in the promoter region of the $\mathrm{p} 15^{\mathrm{INK} 4 \mathrm{~B}}$ and $\mathrm{p} 16^{\mathrm{INK} 4 \mathrm{~A}}$ genes was determined following the procedure described by Herman et al (1996). Chemical DNA modification was performed with the CpGenome DNA modification kit (Oncor, Gaithersburg, Maryland) from $1 \mu \mathrm{g}$ of DNA. The purified DNA was eluted into $35 \mu$ l of water. A 2- to $4-\mu l$ aliquot of template was amplified by PCR using specific primers for the methylated or unmethylated sequences (Table 4). After 40 cycles of amplification in the presence of $1 \times$ PCR buffer II, $2 \mathrm{~mm} \mathrm{MgCl}_{2}, 0.2 \mathrm{~mm}$ dNTPs, $0.15 \mu \mathrm{M}$ of unmethylated or methylated prim- 
Table 4. Primers Used for dPCR, RT-PCR, and MSP

\begin{tabular}{|c|c|c|c|c|}
\hline Determination & \multicolumn{2}{|c|}{ Primer sequence $\left(5^{\prime} \rightarrow 3^{\prime}\right)$} & \multirow{2}{*}{ Size, bp } & $\begin{array}{l}\text { Annealing } \\
\text { temp, }{ }^{\circ} \mathrm{C}\end{array}$ \\
\hline iene deletion & $\mathrm{S}$ & ntisense & & \\
\hline p15 exon 1 & CCAGAAGCAATCCAGGCGCG & AATGCACACCTCGCCAACG & 570 & 60 \\
\hline p16 exon $1 \alpha$ & GAAAGGAGAGGAGGGGCT & GCGCTACCTGATTCCAATTC & 350 & 50 \\
\hline p16 exon 2 & GGAAATTGGAAACTGGAAGC & TCTGAGCTTTGGAAGCTCT & 525 & 55 \\
\hline p14 ${ }^{\mathrm{ARF}}$ exon $1 \beta$ & TCCCAGTCTGCAGTTAAGG & GTCTAAGTCGTTGTAACCCG & 439 & 55 \\
\hline$\beta$-globin & GAAGAGCCAAGGACAGGTAC & CAACTTCATCCACGTTCACC & 268 & $55-60$ \\
\hline \multicolumn{5}{|l|}{ RT-PCR } \\
\hline p15 & CCAGAAGCAATCCAGGCGCG & CGTTGGCAGCCTTCATCG & 725 & 60 \\
\hline p16 & GGCCCTGTAGGACCTTCG & GGAGCAGCATGGAGCCG & 588 & 60 \\
\hline $\mathrm{p} 14^{\mathrm{ARF}}$ & CCCTCGTGCTGATGCTACTGA & ACCAACCAGCGTGTCCAGGAA & 202 & 57 \\
\hline $\mathrm{p} 21^{\mathrm{Cip} 1}$ & CTCAGAGGAGGCGCCATG & GGGCGGATTAGGGCTTCC & 521 & 57 \\
\hline$\beta$-actin & GAGCGGGAAATCGTCCGTGACATT & GATGGAGTTGAAGGTAGTTTCGTG & 234 & 60 \\
\hline \multicolumn{5}{|c|}{ 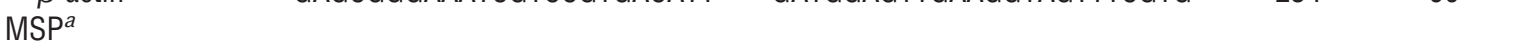 } \\
\hline p15M & GCGTTㅁTATTTTTGCGGTTT & CGTACAATAACCGAACGACCG & 148 & 60 \\
\hline p15U & IGIGAIGIGTTIGTATTTTGIGGTT & 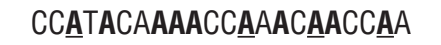 & 154 & 60 \\
\hline p16M & TTATTAGAGGGTGGGGGGATEGC & 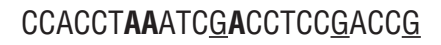 & 234 & 65 \\
\hline p16U & TTATTAGAGGGTGGGGIGGATITGI & ССАССТАААТСААССТТССӒАСС & 234 & 60 \\
\hline \multicolumn{5}{|l|}{ Gene amplification } \\
\hline MDM2 & GAGGGCTTTGATGTTCCTGA & GCTACTAGAAGTTGATGGC & 143 & 53 \\
\hline $\mathrm{DR}$ & CCACTGAATCTGTCCTGGTATG & GTGTGGCATAGTAGTTGTAGTGG & 114 & 53 \\
\hline CDK4 & CATGTAGACCAGGACCTAAGG & GGAGGTCGGTACCAGAGTG & 539 & 57 \\
\hline$\beta$-globin & GAAGAGCCAAGGACAGGTAC & CAACTTCATCCACGTTCACC & 268 & 57 \\
\hline Cyclin D1 & TTCTGCCTTTGATGTTAC & AGGCTGAATCAATGTCTT & 115 & 50 \\
\hline INF $\gamma$ & TCTTTTCTTTCCCGATAGGT & CTGGGATGCTCTTCGACCTC & 150 & 50 \\
\hline \multicolumn{5}{|l|}{ p53 analysis } \\
\hline Exon 5 & TTCCTCTTCCTGCAGTAC & GCCCCAGCTGCTCACCA & 214 & 55 \\
\hline Exon 6 & GGGCTGGTTGCCCAGGGT & TAGTTGCAAACCAGACCTC & 150 & 60 \\
\hline Exon 7 & GTGTTGTCTCTTAGGTTG & TGGCAAGTGGCTCCTGAC & 142 & 55 \\
\hline Exon 8 & CCTATCCTGAGTAGTGGT & GTCCTGCTTGCTTACC & 166 & 55 \\
\hline
\end{tabular}

dPCR, differential PCR; RT-PCR, reverse transcription PCR; MSP, methylation-specific PCR.

${ }^{a}$ Sequence differences between modified primers and unmodified DNA are in boldface type, and differences between methylated/modified and unmethylated/ modified are underlined.

ers, and $1 \mathrm{U}$ of AmpliTaq Gold (Perkin Elmer), the PCR products were analyzed on a $2 \%$ ethidium-bromidestained agarose gel. The presence of methylation was confirmed by the identification of the PCR bands in those samples amplified with the methylated primers. All of the cases tested were evaluated for the presence of an unmethylated-specific fragment, which served as internal control for the quality of the treated DNA.

Expression of the $p 15^{I N K 4 B}, p 16^{I N K 4 A}$, and $p 14^{A R F}$ Genes. Reverse transcription was performed with a GeneAmp RNA-PCR kit (Perkin-Elmer) under the following conditions: aliquots of $2 \mu \mathrm{g}$ of total RNA were incubated with $1 \mu \mathrm{g}$ of $50 \mu \mathrm{M}$ random hexamers. After incubation at $70^{\circ} \mathrm{C}$ for 10 minutes, $4 \mu \mathrm{l}$ of $25 \mathrm{~mm}$ $\mathrm{MgCl}_{2}, 2 \mu \mathrm{l}$ of $10 \mathrm{~mm}$ dNTPs, $200 \mathrm{U}$ of MuLV reverse transcriptase, $20 \mathrm{U}$ of RNase inhibitor, and $2 \mu \mathrm{l} 10$-fold synthesis PCR buffer II were added to complete the 20 $\mu l$ of reverse transcription mixture. After 10 minutes at room temperature, the mixture was incubated at $42^{\circ} \mathrm{C}$ for 30 minutes, followed by $94^{\circ} \mathrm{C}$ for 5 minutes to stop reverse transcription, and $5^{\circ} \mathrm{C}$ for 5 minutes. PCR amplification was performed in duplicate in a 25- $\mu$ l reaction mixture containing $2 \mu$ l of cDNA product as a template, 1.5 to $2.5 \mathrm{~mm} \mathrm{MgCl}_{2}, 0.2 \mathrm{~mm}$ dNTP, $1 \times \mathrm{PCR}$ buffer II, 5\% to 10\% DMSO, $1.5 \cup$ AmpliTaq Gold, and $0.15 \mu \mathrm{M}$ of each set of primers (Table 4). cDNA preparations were also amplified in duplicate in a parallel reaction with $\beta$-actin primers (Table 4). Cycling programs for PCR (40 cycles for $\mathrm{p} 15^{\mathrm{INK} 4 \mathrm{~B}}$ and $\mathrm{p} 16^{\mathrm{INK} 4 \mathrm{~A}}, 30$ cycles for $\mathrm{p} 14^{\mathrm{ARF}}$, and 25 cycles for $\beta$-actin) were optimized to ensure the lineal amplification and to make a semiquantitative estimation of the generated PCR products comparing band intensity from $\mathrm{p} 15^{\mathrm{INK} 4 \mathrm{~B}}, \mathrm{p} 16^{\mathrm{INK} 4 \mathrm{~A}}$, and $\mathrm{p} 14^{\mathrm{ARF}}$ with those generated with the $\beta$-actin primers after image analysis (1D Image Analysis Software, Eastman Kodak, Rochester, New York). PCR products corresponding to each case were electrophoresed in the same 1.5\% ethidium-bromide-stained agarose gel, visualized, photographed, and analyzed.

\section{p53 Mutation Analysis and p21 WAF1/Cip1 Expression}

p53 Sequencing Analysis. High molecular weight DNA was used in four different PCR-amplification reactions (exons 5 to 8) performed in $50 \mu$ l of reaction mixture containing approximately $100 \mathrm{ng}$ of genomic DNA, $1 \times$ PCR buffer II, $1.5 \mathrm{~mm}$ of $\mathrm{MgCl}_{2}, 0.5 \mu \mathrm{M}$ for 
each primer (Table 4), $0.2 \mathrm{~mm}$ of dNTP, and $1 \mathrm{U}$ of AmpliTaq. After 35 cycles, PCR products were purified with Centricon columns (Amicon, Beverly, Massachusetts) and sequenced on an Applied Biosystem model 310 automated sequencer (Foster City, California) using the dRhodamine terminator cycle sequencing ready reaction kit (PE Applied Biosystems; Warrington, United Kingdom).

RT-PCR of $p 21^{\text {WAF1/Cip } 1 . ~ A n a l y s i s ~ o f ~ p 21 W A F 1 / ~}$ Cip1 RNA expression was performed as described above for the $\mathrm{p} 15^{\mathrm{INK} 4 \mathrm{~B}}, \mathrm{p} 16^{\mathrm{INK} 4 \mathrm{~A}}$, and $\mathrm{p} 14^{\mathrm{ARF}}$ genes, but with 25 cycles of PCR amplification and a $57^{\circ} \mathrm{C}$ annealing temperature (Table 4).

\section{Analysis of the MDM2, CDK4, and Cyclin D1 Gene Amplification}

Gene amplification of the MDM2, CDK4, and cyclin D1 genes was determined by dPCR using two sets of primers, one corresponding to the target gene and the other to an internal control gene sequence; the dopamine receptor (DR), the $\beta$-globin, and the interferon gamma (INF $\gamma$ ) genes for MDM2, CDK4, and cyclin D1 analysis, respectively (Table 4). PCR-reactions were performed in $25 \mu \mathrm{l}$ of a solution containing $250 \mathrm{ng}$ of DNA, $1 \times$ PCR buffer II, $1.5 \mathrm{~mm} \mathrm{MgCl}_{2}, 0.2 \mathrm{~mm}$ dNTP, 0.6 AmpliTaq, and $0.2 \mu \mathrm{M}$ for each primer. Annealing temperatures are indicated in Table 4. After 28 cycles of amplification, PCR products were visualized on a $1.5 \%$ to $2.5 \%$ ethidium-bromide-stained agarose gel. A higher band intensity for the target genes than the reference bands confirmed a gene amplification. Positive, negative, and water controls were employed in each experiment.

\section{Cytogenetic Studies and FISH Technique}

Tumor cells from the original specimens, as well as from xenografted tumors, were harvested after 24 hours (direct preparations) and after 3 to 7 days in culture. The specimens were processed as previously described (Llombart-Bosch et al, 1990; Noguera et al, 2001).

FISH was performed on tumor cells for chromosomes and nuclei after short-term culture using standard procedures. Analysis of $t(11 ; 22)$ was performed using two combinations of probes: chromosome $11 \alpha-$ satellite centromere-specific probe (D11Z1) and coatasome 22 total chromosome probe (wcp22) and coatasomes 11 and 22 total chromosome probes (wcp11/wcp22). Coatasome 9 total chromosome probe (wcp9) was used in Case 4 (Noguera et al, 2001). All probes were obtained from Oncor.

\section{Statistical Analysis}

The Kaplan-Meier proportional risk test (log rank) was used to study the effect of the molecular alterations analyzed on overall survival. This test is included in the SPSS statistical package (version 9.0).

\section{Acknowledgements}

The authors are grateful to Estela Pons and Elisa Alonso for their technical assistance.

\section{References}

Abudu A, Mangham DC, Reynolds GM, Pynsent PB, Tillman RM, Carter SR, and Grimer RJ (1999). Overexpression of p53 protein in primary Ewing's sarcoma of bone: Relationship to tumor stage, response and prognosis. Br J Cancer 79:11851189.

Cairns P, Mao L, Merlo A, Lee DJ, Schwab D, Eby Y, Tokino $K$ van der Riet P, and Blaugrund JE (1994). Rate of p16 (MTS1) tumor suppressor gene mutations in primary tumors with p16 loss. Science 265:415-416.

de Alava E, Antonescu CR, Panizo A, Leung D, Meyers PA, Huvos AG, Pardo-Mindán FJ, Healey $\mathrm{JH}$, and Ladanyi M (2000). Prognostic impact of p53 status in Ewing sarcoma. Cancer 89:783-792.

de Alava E, Kawai A, Healey JH, Fligman I, Meyers P, Huvos AG, Gerald WL, Jhanwar SC, Argani P, Antonescu CR, Pardo-Mindan FJ, Ginsberg J, Womer R, Lawlor ER, Wonder J, Andrulis I, Sorensen PH, Barr FG, and Ladanyi M (1998a). EWS-FLI1 fusion transcript structure is an independent determinant of prognosis in Ewing's sarcoma. J Clin Oncol 16:1248-1255.

de Alava E, Lozano MD, Patiño A, Sierrasesumaga L, and Pardo-Mindan FJ (1998b). Ewing family tumors: Potential prognostic value of reverse-transcriptase polymerase chain reaction detection in minimal residual disease in peripheral blood samples. Diagn Mol Pathol 7:152-157.

Delattre O, Zucman J, Melot T, Garau XS, Zucker JM, Lenoir JM, Ambros PF, Sheer D, Turc-Carel C, Triche TJ, Aurias A, and Thomas $G$ (1994). The Ewing family of tumors: A subgroup of small round-cell tumors defined by specific chimeric transcripts. N Engl J Med 331:294-299.

Drexler HG (1998). Review of alterations of the cyclindependent kinase inhibitor INK4 family genes p15, p16, p18 and p19 in human leukemia-lymphoma cells. Leukemia 12: 845-859.

Esteller M, Tortola S, Toyota M, Capella G, Peinado MA, Baylin SB, and Herman JG (2000). Hypermethylationassociated inactivation of $\mathrm{p} 14^{\mathrm{ARF}}$ is independent of $\mathrm{p} 16^{\mathrm{INK} 4 a}$ methylation and p53 mutational status. Cancer Res 60:129133.

Gonzalez-Zulueta M, Bender CM, Yang AS, Nguyen T, Beart RW, Van Tornout JM, and Jones PA (1995). Methylation of the $5^{\prime} \mathrm{CpG}$ island of the p16/CDKN2 tumor suppressor gene in normal and transformed human tissues correlates with gene silencing. Cancer Res 55:4531-4535.

Graña X and Reddy EP (1995). Cell cycle control in mammalian cells: Role of cyclins, cyclin dependent kinases (CDKs), growth suppressor genes and cyclin dependent kinase inhibitors (CDKIs). Oncogene 11:211-219.

Hannon GJ and Beach D (1994). p15 INK4B is a potential effector of TGF- $\beta$-induced cell cycle arrest. Nature 371:257261.

Herman JG, Graff JR, Myohanen S, Nelkin BD, and Baylin SB (1996). Methylation-specific PCR: A novel PCR assay for methylation status of $\mathrm{CpG}$ islands. Proc Natl Acad Sci USA 93:9821-9826. 
Hollstein M, Hergenhahn M, Yang Q, Bartsch H, Wang ZQ, and Hainaut $P$ (1999). New approaches to understanding p53 gene tumor mutation spectra. Mutat Res 431:199-209.

Huschtscha LI and Reddel RR (1999). P16(INK4a) and the control of cellular proliferative life span. Carcinogenesis 20 : 921-926.

Jen J, Harper JW, Bigner SH, Bigner DD, Papadopuolus N, Markowitz S, Willson JKV, Kinzler KW, and Vogelstein B (1994). Deletion of p16 and p15 genes in brain tumors. Cancer Res 54:6353-6358.

Johnson DG and Walker CL (1999). Cyclins and cell cycle checkpoints. Annu Rev Pharmacol Toxicol 39:295-312.

Kamb A, Gruis NA, Weaver-Feldhaus J, Liu Q, Harshman K, Tavtigian SV, Stockert E, Day RS-3 ${ }^{\text {rd }}$, Johnson BE, and Skolnick MH (1994). A cell cycle regulator potentially involved in genesis of many tumor types. Science 264:436-440.

Khatib ZA, Matsushime H, Valentine M, Shapiro DN, Sherr CJ, and Look AT (1993). Coamplification of the CDK4 gene with MDM2 and GLI in human sarcomas. Cancer Res 53: 5535-5541.

Kovar H (1998). Progress in the molecular biology of Ewing tumors. Sarcoma 2:3-17.

Kovar H, Jug G, Aryee DN, Zoubek A, Ambros P, Gruber B, Windhager R, and Gadner H (1997). Among genes involved in the RB dependent cell cycle regulatory cascade, the p16 tumor suppressor gene is frequently lost in the Ewing family of tumors. Oncogene 15:2225-2232.

Ladanyi M, Lewis R, Jhanwar SC, Gerald W, Huvos AG, and Healey JH (1995). MDM2 and CDK4 gene amplification in Ewing's sarcoma. J Pathol 175:211-217.

Liggett WH and Sidransky D (1998). Role of the p16 tumor suppressor gene in cancer. J Clin Oncol 16:1197-1206.

Llombart-Bosch A (1999). Ewing's sarcoma and peripheral primitive neuroectodermal tumor of bone and soft tissue. Int J Surg Pathol 7:185-192.

Llombart-Bosch A, Carda C, Peydro-Olaya A, Noguera R, Perez-Bacete M, Pellin A, and Boix J (1990). Soft tissue Ewing's sarcoma: Characterization in established cultures and xenografts with evidence of a neuroectodermic phenotype. Cancer 66:2589-2601.

Llombart-Bosch A, Pellín A, Carda C, Noguera R, Navarro S, and Peydró-Olaya A (2000). Soft tissue Ewing/PNET (Es/ PPNET) with atypical clear cell pattern showing a new type of EWS-FEV fusion transcript. Diagn Mol Pathol 9:137-144.

Lundberg AS and Weinberg RA (1999). Control of the cell cycle and apoptosis. Eur J Cancer 35:531-539.

Mao L, Merlo A, Bedi G, Shapiro GI, Edwars CD, Rollins BJ, and Sidransky D (1995). A novel p16 ${ }^{\text {INK4A }}$ transcript. Cancer Res 55:2995-2997.

Martín-Castellanos C and Moreno S (1997). Recent advances on cyclins, CDKs and CDK inhibitors. Trends Cell Biol 7:9598.

Merlo A, Herman JG, Mao L, Lee DJ, Gabrielson E, Burger PC, Baylin SB, and Sidransky D (1995). 5'CpG island methylation is associated with transcriptional silencing of the tumor suppressor p16/CDKN2/MTS1 in human cancers. Nat Med 1:686-692.

Meye A, Würl P, Hinze R, Berger D, Bache M, Schmidt M, Rath FW, and Taubert H (1998). No p16 1 INK4A/CDKN2/MTS1 mutations independent of p53 status in soft tissue sarcomas. J Pathol 184:14-17.

Nobori T, Miura K, Wu DJ, Lois A, Takabayashi K, and Carson DA (1994). Deletions of the cyclin-dependent kinase-4 inhibitor gene in multiple human cancers. Nature 368:753-756.

Noguera R, Pellin A, Navarro S, Carda C, and LlombartBosch A (2001). Translocation (10;11;22)(p14;q24;q12) characterized by fluorescence in situ hybridization in a case of Ewing's tumor. Diagn Mol Pathol 10:2-8.

Okamoto A, Demetrik DJ, Spillare EA, Hagiwara K, Hussain SP, Bennett WP, Forrester K, Gerwing B, Serrano M, Beach DM, and Harris C (1994). Mutations and altered expression of p16INK4 in human cancer. Proc Natl Acad Sci USA 91: 11045-11049.

Orlow I, Drobnajk M, Zhang ZF, Lewis J, Woodruff JM, Brennan MF, and Cordon-Cardo C (1999). Alterations of INK4A and INK4B genes in adult soft tissue sarcomas: Effect on survival. J Natl Cancer Inst 91:73-79.

Park YK, Chi SG, Kim YM, Park HR, and Unni KK (1999). Mutation alteration of the p16CDKN2 tumor suppressor gene is infrequent in Ewing's sarcoma. Oncol Rep 6:1261-1266.

Patiño-Garcia A and Sierrasesúmaga L (1997). Analysis of the p16INK4A and TP53 tumor suppressor gene in bone sarcoma pediatric patients. Cancer Genet Cytogenet 98:50-55.

Pellín A, Boix J, Blesa JR, Noguera R, Carda C, and Llombart-Bosch A (1994). EWS/FLI1 rearrangement in small round cell sarcomas of bone and soft tissue detected by reverse transcriptase polymerase chain reaction amplification. Eur J Cancer 30A:827-831.

Schneider-Stock R, Rading K, and Roessner A (1997). Loss of heterozygosity on chromosome 9p21 (p16 gene) uncommon in soft tissues sarcomas. Mol Carcinog 18:63-65.

Serrano M, Hannon GJ, and Beach D (1993). A new regulatory motif in cell cycle control causing specific inhibition of cyclin D/CDK4. Nature 366:704-707.

Sharpless EN and DePinho RA (1999). The INK4/ARF locus and its two gene products. Curr Opin Genet Dev 9:22-30.

Sherr CJ (1996). Cancer cell cycles. Science 274:1672-1677.

Spruck CM, Gonzalez Zulueta M, Shibata A, Simonean AR, Liu MF, Gonzales F, Tsai YC, and Jones PA (1994). p16 gene in uncultured tumors. Nature 370:183-184.

Stone S, Jiang P, Dayananth P, Tavtigian SV, Katcher H, Parry D, Peters G, and Kamb A (1995). Complex structure and regulation of the P16 (MTS1) locus. Cancer Res 55: 2988-2994.

Tsuchiya T, Sekine K, Hinohara S, Namiki T, Nobori T, and Kaneko $Y$ (2000). Analysis of the p16INK4, p14ARF, p15, TP53, and MDM2 genes and their prognostic implications in osteosarcoma and Ewing sarcoma. Cancer Genet Cytogenet 120:91-98.

Turc-Carel C, Aurias A, Mugneret F, Lizard S, Sidaner I, Volk C, Thiery JP, Olschwang S, Philip I, Berger MP, Philip T, Lenoir GM, and Mazabrand A (1988). Chromosomes in Ewing's sarcoma. I. An evaluation of 85 cases of remarkable consistency of $\mathrm{t}(11 ; 22)(\mathrm{q} 24 ; \mathrm{q} 12)$. Cancer Genet Cytogenet 32:229-238.

Wei G, Antonescu CR, de Alava E, Leung D, Huvos AG, Meyers PA, Healey JH, and Ladanyi M (2000). Prognostic impact of INK4A deletion in Ewing sarcoma. Cancer 89:793799. 
Wei G, Lonardo F, Ueda T, Kim T, Huvos AG, Healey JH, and Ladanyi M (1999). CDK4 gene amplification in osteosarcomas: Reciprocal relationship with INK4A gene alterations and mapping of $12 \mathrm{q} 13$ amplicons. Int $\mathrm{J}$ Cancer 80:199-204.

Weinberg RA (1995). The retinoblastoma protein and cell cycle control. Cell 81:323-330.
Yao J, Pollock RE, Lang A, Tan M, Pisters PWT, Goodrich D, El-Naggar A, and Yu D (1998). Infrequent mutation of the p16/MTS1 gene and overexpression of cyclin-dependent kinase 4 in human primary soft-tissue sarcoma. Clin Cancer Res 4:1065-1070. 